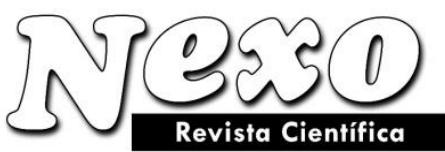

Vol. 34, No. 01, pp. 112-119/Marzo 2021

\title{
Synthesis of an organic metal nanoporous structure for controlled azathioprine delivery
}

\section{Síntesis de una estructura nanoporosa de metal orgánico para el suministro controlado de azatioprina}

\author{
Maral Maghsoudloo*, Majid Abdouss, Elaheh Kowsari \\ Department of Chemistry, Amirkabir University of Technology, Tehran, Iran \\ maralmag71@gmail.com
}

(recibido/received: 03-January-2021; aceptado/accepted: 07-February-2021)

\begin{abstract}
New drug delivery systems are highly efficient in diseases diagnosis and treatment and also controlled release of drugs. The use of this technology has given rise to the invention of new porous nanoparticles which are called metal organic frameworks (MOFs). In the present research, a kind of MOFs with formula $\mathrm{Cu}_{3}$ (BTC) $)_{2}$ (HKUST-1, BTC $1 / 4$ benzene-1,3,5-tricarboxylate) with $\mathrm{Fe}_{3} \mathrm{O}_{4}$ magnetic nanoparticles (MNPs) as a core have been able to create three-dimensional magnetic porous structures. This magnetic and porous structure and the pores capability in being controlled have made these frameworks to be used as one of the best carriers in drug delivery. This system could magnetically be directed to the considered point inside body if it contains a drug that has side effects and may harm other body organs. Azathioprine is used in rheumatoid arthritis, granulomatosis with polyangiitis, Crohn's disease, ulcerative colitis, systemic lupus erythematosus, and in kidney transplants to prevent rejection. However, in the present work we consider the drug injection for kidney transplants to prevent rejection.

Keywords: MOF, Nanoporous structure, MNPs, Drug release, Azathioprine.
\end{abstract}

\section{RESUMEN}

Los nuevos sistemas de administración de fármacos son altamente eficientes en el diagnóstico y tratamiento de enfermedades y también en la liberación controlada de fármacos. El uso de esta tecnología ha dado lugar a la invención de nuevas nanopartículas porosas que se denominan estructuras organometálicas (MOF). En la presente investigación, una especie de MOF con fórmula Cu3 (BTC) 2 (HKUST-1, BTC 1/4 benceno-1,3,5-tricarboxilato) con nanopartículas magnéticas (MNP) de Fe3O4 como núcleo han podido crear tres- estructuras porosas magnéticas dimensionales. Esta estructura magnética y porosa y la capacidad de control de los poros han hecho que estas estructuras se utilicen como uno de los mejores vehículos en la administración de fármacos. Este sistema podría dirigirse magnéticamente al punto considerado dentro del cuerpo si contiene un medicamento que tiene efectos secundarios y puede dañar otros órganos del cuerpo. La azatioprina se usa en artritis reumatoide, granulomatosis con poliangeítis, enfermedad de Crohn, colitis ulcerosa, lupus eritematoso sistémico y en trasplantes de riñón 
para prevenir el rechazo. Sin embargo, en el presente trabajo consideramos la inyección de fármacos para trasplantes de riñón para prevenir el rechazo.

Palabras clave: MOF, estructura nanoporosa, MNP, liberación de fármaco, azatioprina.

\section{INTRODUCTION}

Magnetic nanoparticles (MNPs) are responsive to external magnetic field. The size, compositions and the synthesis procedure of these magnetic nanoparticles are different according to their application. Super paramagnetic nanoparticles have tremendous applications in drug delivery and recently have drawn significant attention among pharmaceutical chemists. These materials due to possessing high magnetic property could highly be affected by an external magnetic field and it has created a vast area in drug delivery as magnetic targeted carriers (Dobson, 2006; Goodwin, Peterson, Hoh, \& Bittner, 1999; Huang, Lu, \& Chen, 2017; Lübbe, Alexiou, \& Bergemann, 2001; McBain, Yiu, \& Dobson, 2008). Drug delivery systems based on nanotechnology because of the increase in the time of the drug presence in blood, the decrease in toxicity and the increase in the drug lifetime, have given rise to an underlying improvement in medicinal treatments (Hughes, 2017; Li \& Mooney, 2016; Parveen, Misra, \& Sahoo, 2012; Tibbitt, Dahlman, \& Langer, 2016; Vader, Mol, Pasterkamp, \& Schiffelers, 2016; Webber \& Langer, 2017).

Although zeolite as a porous material has been very successful in industrial applications, they are not successful in drug delivery systems because their pores size is not enough small to accept tiny molecules (Colella, 2011). Accordingly, researchers are trying to overcome the problems and are challenging to modify it for medicinal applications (Ananthoji et al., 2011). Metal organic frameworks (MOF) could easily be designed to accept guest tiny molecules. Designing these materials generally seems to be an art than a science because in their construction process chemists are able to control the crystalline structure, pores size and chemical and physical properties. In addition, they alleviate the side effects of the active pharmaceutical ingredient (API) and can increase in the efficiency of drug. Accordingly, in recent years, they have been extensively investigated especially in the field of drug delivery. In addition to the above mentioned advantages, MOFs have very unified pores (Akhtar, Chen, AlDamen, \& Tong, 2017; Deria, Yu, Balaraman, Mashni, \& White, 2016; Janiak \& Vieth, 2010; Lee, Kim, \& Ahn, 2013; Reinsch et al., 2013; Shekhah, Liu, Fischer, \& Wöll, 2011).

MOFs due to possessing organic and inorganic parts in their structure provide underlying advantages in drug delivery such as biocompatibility, loading high amounts of drug and controlled drug release. One of the other goals of developing these systems is to obtain a system which has the lowest toxicity in body (Gupta et al., 2019; Ibrahim, Sabouni, \& A Husseini, 2017; Lazaro \& Forgan, 2019; Orellana-Tavra, Köppen, Li, Stock, \& Fairen-Jimenez, 2020; Park, Kim, Murray, Koo, \& Kim, 2017; Xie et al., 2018; Xue et al., 2019). In the present work we synthesize $\mathrm{Cu}_{3}(\mathrm{BTC})_{2}$ (HKUST-1, BTC 1/4 benzene-1,3,5tricarboxylate) encapsulated with $\mathrm{Fe}_{3} \mathrm{O}_{4} \mathrm{MNPs}\left(\mathrm{Fe}_{3} \mathrm{O}_{4} / \mathrm{Cu}_{3}(\mathrm{BTC})_{2}\right)$ and load azathioprine inside it in order to inject for kidney transplants to prevent rejection. To the best of our knowledge, this is the first application of a MOF for azathioprine delivery. 


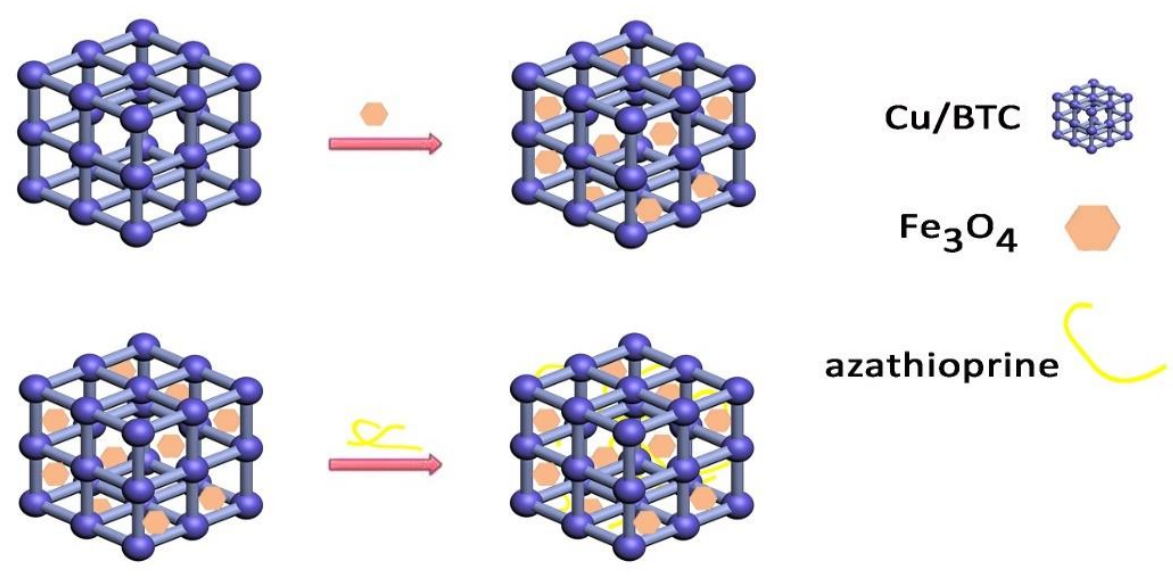

Figure 1. The synthesis of $\mathrm{Fe}_{3} \mathrm{O}_{4} / \mathrm{Cu}_{3}(\mathrm{BTC})_{2} \mathrm{MOF}$ and loading azathioprine inside it.

\section{EXPERIMENTAL}

General: $\quad \mathrm{Cu}\left(\mathrm{CO}_{2} \mathrm{CH}_{3}\right)_{2}, \quad \mathrm{FeCl}_{2}, \quad \mathrm{Fe}_{2}\left(\mathrm{SO}_{4}\right)_{3}, \quad$ DMSO, dimethylformamide, $\mathrm{NaHCO}_{3}$, ethylenediaminetetraacetic acid, sodium azide, $\mathrm{Na}_{2} \mathrm{HPO}_{4}-7 \mathrm{H}_{2} \mathrm{O}$, ethanol, benzene-1,3,5-tricarboxylic acid and azathioprine were purchased from Merck, Fluka and Aldrich. FE-SEM images were obtained on a Sigma Zeiss. XRD measurements were carried out using a JEOL JDX-8030 (30 kV, 20 mA). UV/VIS Spectroscopy was obtained by PerkinElmer lambda 25 uv/vis spectrometer.

Preparation of phosphate buffer: $1000 \mathrm{~mL}$ of distilled water in a suitable container was prepared. $7.8 \mathrm{~g}$ $\mathrm{NaCl}, 1.82 \mathrm{~g} \mathrm{Na}_{2} \mathrm{HPO}_{4}-7 \mathrm{H}_{2} \mathrm{O}$ and $0.23 \mathrm{~g} \mathrm{NaH}_{2} \mathrm{PO}_{4} \mathrm{H}_{2} \mathrm{O}$ were dissolved in the solution. The solution $\mathrm{pH}$ was adjusted by $\mathrm{HCl}$ in 7.4 .

Preparation of dialysis container: Dialysis container was submerged into a solution containing $2 \%$ $\mathrm{NaHCO}_{3}$ and $0.05 \%$ ethylenediaminetetraacetic acid and boiled for 10 minutes. After cooling it remained inside sodium azide for 4 hours.

Synthesis of $\mathrm{Fe}_{3} \mathrm{O}_{4}$ MNPs: $\mathrm{FeCl}_{3} \cdot 6 \mathrm{H}_{2} \mathrm{O}$ and $\mathrm{FeCl}_{2} \cdot 4 \mathrm{H}_{2} \mathrm{O}$ with molar ratio of 1:2 were dissolved in ethanol in a $25 \mathrm{cc}$ suitable container. Then, $\mathrm{NaOH}$ solution $\left(3 \mathrm{~mol} \cdot \mathrm{L}^{-1}\right)$ was loaded into the solution by using of a peristaltic pump and stirred magnetically for $30 \mathrm{~min}$. the final $\mathrm{pH}$ was 10 . Next, the sodiumcitrate and oleic acid were respectively added into the suspensions to modify the obtained $\mathrm{Fe}_{3} \mathrm{O}_{4} \mathrm{MNPs}$ for $12 \mathrm{~h}$.

Synthesis of $\mathrm{Fe}_{3} \mathrm{O}_{4} / \mathrm{Cu}_{3}(\mathrm{BTC})_{2} \mathrm{MOF}: 0.5 \mathrm{~g} \mathrm{H} 3 \mathrm{BTC}$ was dissolved in $80 \mathrm{~mL}$ ethanol and $0.1 \mathrm{~g} \mathrm{Fe}_{3} \mathrm{O}_{4} \mathrm{MNPs}$ were added inside the solution. In this stage the color of the solution changed into orange. Then, $0.68 \mathrm{~g}$ $\mathrm{Cu}(\mathrm{OAc})_{2}$ was added to the solution and heated for $4 \mathrm{~h}$ on a heater. The obtained solution was washed by distilled water and ethanol. The solution was centrifuged and the product was separated. It was placed inside oven at $80{ }^{\circ} \mathrm{C}$ for half an hour.

Azathioprine loading inside the MOF: The loading process was carried out to insert drug particles inside the synthesized magnetic MOF pores. Because azathioprine in $14 \mathrm{ppm}$ has UV absorption, this amount of the drug was dissolved in a solution containing distilled water and ethanol in a suitable $20 \mathrm{~mL}$ container. Then, 3 flasks with the drug to nanocarrier ratio of 2:1, 1:1 and 1:2 were prepared to obtain three different concentrations of drug and MOF in order to find out the best ratio for the loading. The three flasks were shaken on a shaker with $350 \mathrm{rpm}$ at room temperature. After three days, the loading capability of the three 
samples was investigated by UV spectroscopy. Next, the products were dried at $70{ }^{\circ} \mathrm{C}$ for $24 \mathrm{~h}$. This temperature doesn't damage the drug because its decomposition temperature happens at more than $200{ }^{\circ} \mathrm{C}$.

Drug release: A suitable amount of the three obtained samples were loaded into the prepared dialysis container and it was immersed inside a falcon $30 \mathrm{~mL}$ centrifuge containing phosphate buffer. The falcon tube was centrifuged with $350 \mathrm{rpm}$ at $37{ }^{\circ} \mathrm{C}$. The samples are cationic because of the drug presence. Hence, these cations could be replaced with phosphate buffer cations, which gives rise to the extraction of the drug from the samples structure. To avoid this problem, $3 \mathrm{~mL}$ of phosphate buffer was taken and a same amount of fresh buffer was replaced. The release profile was obtained by soaking the samples in 90 $\mathrm{mL}$ of a simulated body fluid, SBF (1 $\mathrm{mg}$ of azathioprine of the three prepared samples per $\mathrm{mL}$ of fluid), and measuring the drug concentration in the fluid by means of a UV-vis spectrophotometer.

\section{RESULTS AND DISCUSSION}

SEM images were used for showing nanostructured surface of both $\mathrm{Fe}_{3} \mathrm{O}_{4}$ MNPs and $\mathrm{Fe}_{3} \mathrm{O}_{4} / \mathrm{Cu}_{3}(\mathrm{BTC})_{2}$ (Fig. 2). Because of $\mathrm{Cu}_{3}(\mathrm{BTC})_{2}$ coating surrounded by $\mathrm{Fe}_{3} \mathrm{O}_{4}$ MNPs, MOFs are observed as cubic particles (Fig. 2, E and F). Furthermore, particle size distribution chart was obtained and it was realized that the particle size distribution is narrow and the size of most of the particles is about $15-20 \mathrm{~nm}$.
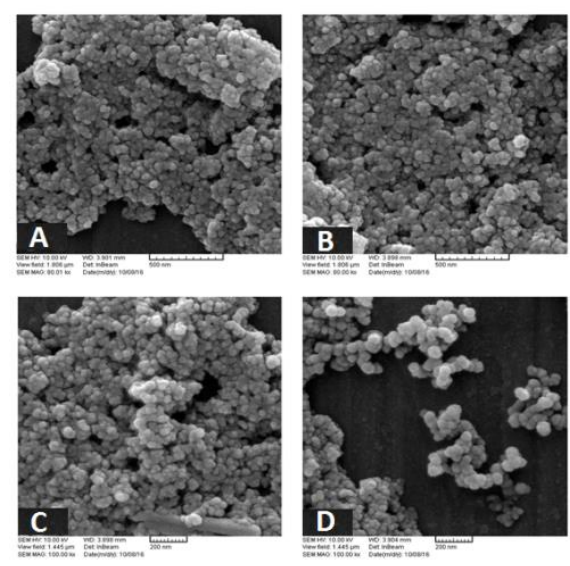
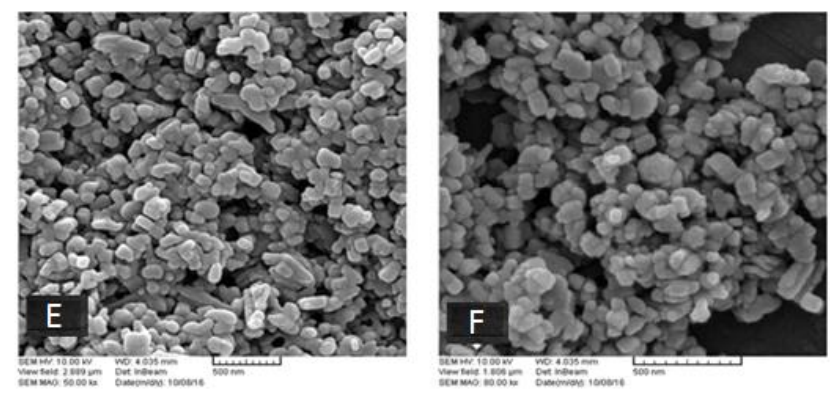

Figure 2. SEM images of $\mathrm{Fe}_{3} \mathrm{O}_{4}$ MNPs (A-D) and $\mathrm{Fe}_{3} \mathrm{O}_{4} / \mathrm{Cu}_{3}(\mathrm{BTC})_{2}(\mathrm{E}$ and $\mathrm{F})$.

FT-IR spectroscopy for both $\mathrm{Fe}_{3} \mathrm{O}_{4} / \mathrm{Cu}_{3}(\mathrm{BTC})_{2}$ and azathiaprine were obtained for charachterization (Fig. 3 ). An intense peak at 3400 to $3600 \mathrm{~cm}^{-1}$ is related to the water absorbed by the sample. The peak at 1500 $1600 \mathrm{~cm}^{-1}$ is related to $\mathrm{C}-\mathrm{C}$ stretching vibrations. The peak appeared at $1550-1610 \mathrm{~cm}^{-1}$ is related to CO$\mathrm{OH}$ (carboxylic acid) indicating connecting factors in MOFs. The appeared peaks at $1395-1405 \mathrm{~cm}^{-1}$ are related to $\mathrm{C}-\mathrm{O}$ stretching vibrations. The peaks at $1350-1450 \mathrm{~cm}^{-1}$ show $\mathrm{S}=\mathrm{O}$ (sulphate) bond. The peaks at $1400-1500 \mathrm{~cm}^{-1}$ are related to aromatic rings. The peaks at $1615-1700 \mathrm{~cm}^{-1}$ are shown $\mathrm{C}=\mathrm{N}$ bond. $\mathrm{N}=\mathrm{O}$ peak could be seen at $1500-1600 \mathrm{~cm}^{-1}$. Stretching C-H vibrations are appeared at $2850-3000 \mathrm{~cm}^{-1}$. 

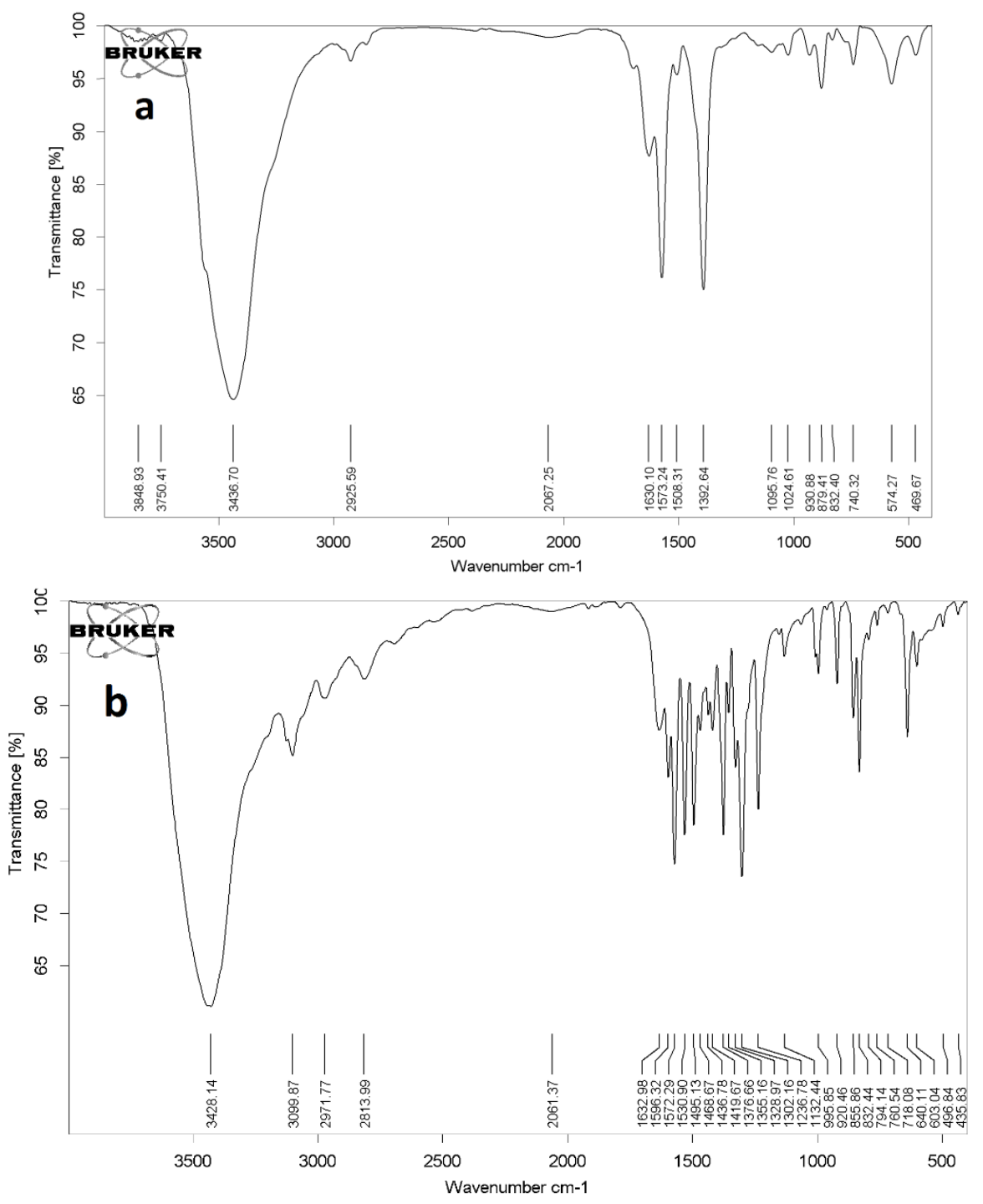

Figure 3. FT-IR spectrum of a) $\mathrm{Fe}_{3} \mathrm{O}_{4} / \mathrm{Cu}_{3}(\mathrm{BTC})_{2}$ and b) azathioprine.

The effective loading of azathioprine by the MOF MNPs when immersed into the hexane solution of the drug can be monitored by TGA, which indicates a maximum of $37 \mathrm{wt} \%$ of azathioprine. Comparing a and b diagrams in Fig. 4, it can be said that after drug loading TGA diagram shows $37 \mathrm{wt} \%$ loss which is due to the decomposition of the drug in temperature ranging from 300 to $400{ }^{\circ} \mathrm{C}$. It can be concluded that this weight loss in this range of temperature confirms the effective uptake of azathioprine in the synthesized nanocarrier. 


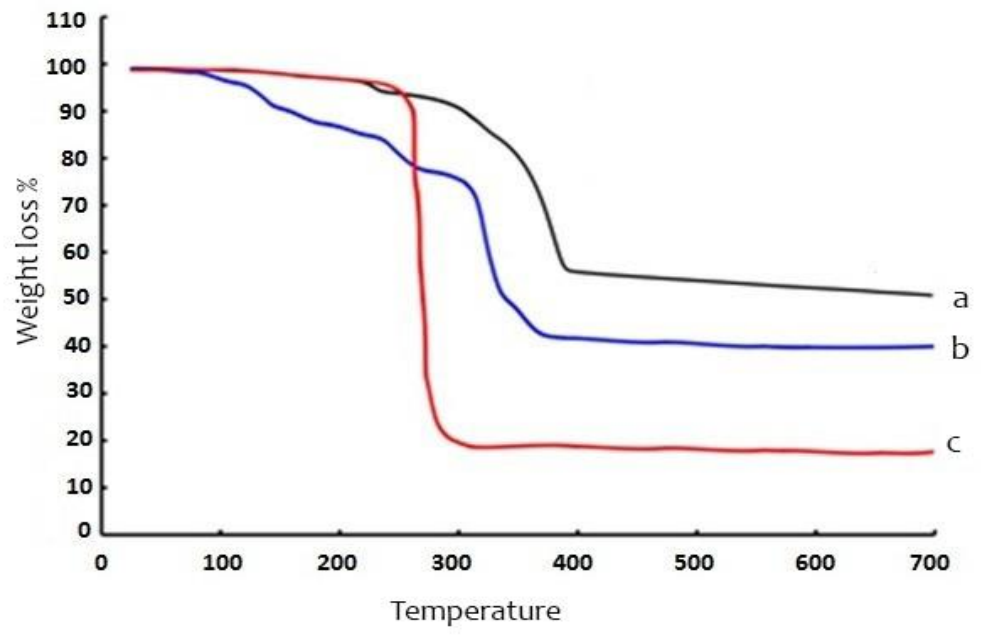

Figure 4. TGA diagram of a) before drug loading, b) after drug loading and c) azathioprine.

Fig. 5 shows the percentage of azathioprine release as a function of time for the $\mathrm{Fe}_{3} \mathrm{O}_{4} / \mathrm{Cu}_{3}(\mathrm{BTC})_{2}$ with the three obtained samples with the drug to nanocarrier ratio of 2:1, 1:1 and 1:2 loaded with azathioprine. As it can be seen from the release diagrams, by increasing the nanocarrier ratio the drug release conditions improve. According diagram c, it can be said that it releases the loaded drug gently and with high percentage $(85 \%)$. The drug to nanocarrier ratio of $1: 1$ (Fig. 5, b) has a medium release with medium percentage $(71 \%)$ and for the ratio of $2: 1$ (Fig. 6, a) the highest release percentage happens after $72 \mathrm{~h}$ (49\%). The azathioprine release in drug to nanocarrier ratio of $1: 2$ (Fig. 5 , c) increases by passing the time and reaches to its highest point after $100 \mathrm{~h}$. It is noteworthy that, after releasing azathioprine the XRD of $\mathrm{Fe}_{3} \mathrm{O}_{4} / \mathrm{Cu}_{3}(\mathrm{BTC})_{2}$ was obtained and it showed no loss of structural ordering.

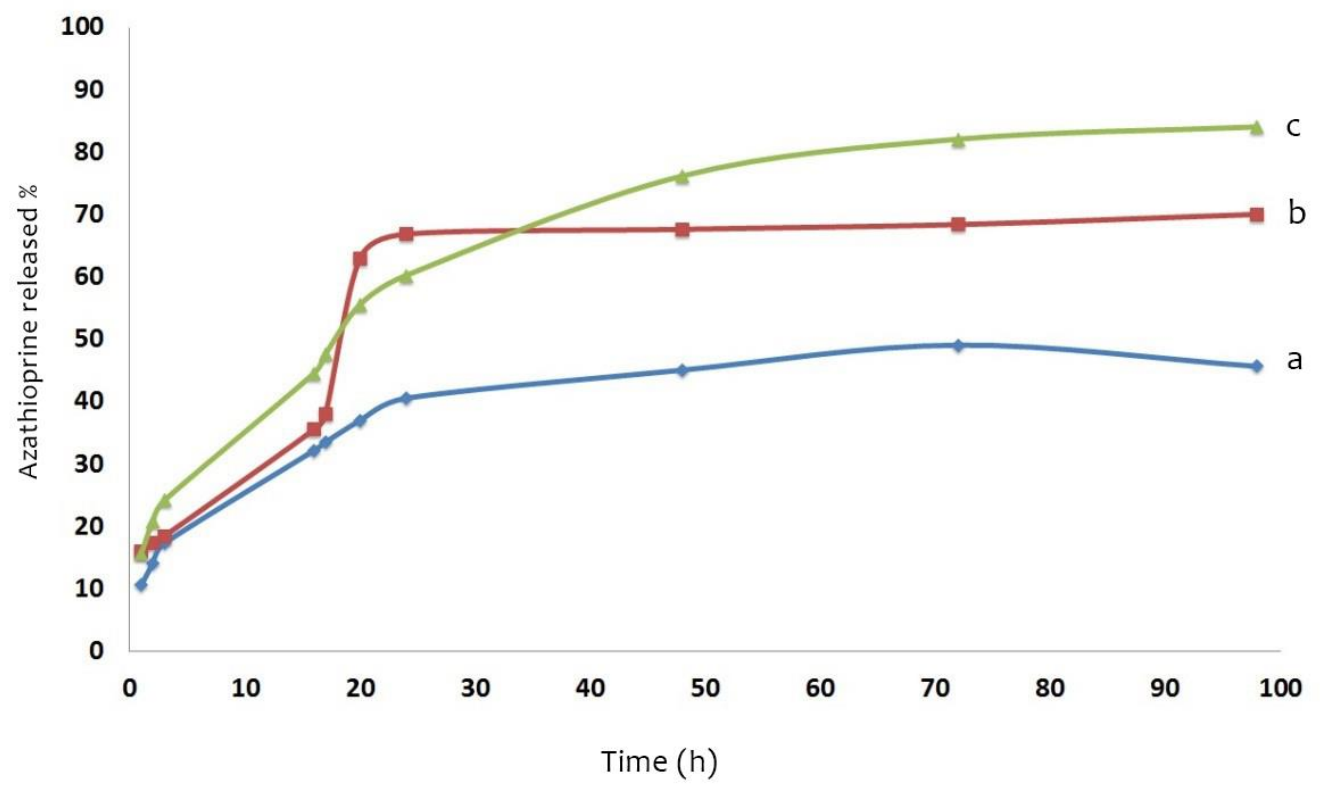

Figure 5. Azathioprine $\%$ release from $\mathrm{Fe}_{3} \mathrm{O}_{4} / \mathrm{Cu}_{3}(\mathrm{BTC})_{2}$ in drug to MOF ratio of a) 2:1, b) 1:1 and c) 1:2. 


\section{CONCLUSION}

We developed an interesting MOFs property which is their capability for accepting and delivering organic compounds. For the first time, we used MOF MNPs as nanocarrier for azathioprine delivery. The used nanocarrier was $\mathrm{Fe}_{3} \mathrm{O}_{4} / \mathrm{Cu}_{3}(\mathrm{BTC})_{2}$ which was synthesized in a facial way. We showed that the synthesized MOF pore size was $2.1 \mathrm{~nm}$ and the size of the azathioprine molecules estimated to be $\approx 1.4 \times$ $0.7 \mathrm{~nm}$. Hence, the drug molecules could fit inside the MOF pores. The drug loading was monitored by TGA and it was estimated to be $37 \%$. The percentage of azathioprine release was investigated by SBF and UV which in the optimized conditions after $100 \mathrm{~h}$ it reached to $85 \%$. This MOF is magnetic and could be directed to the considered part of patient body then start to release the drug to avoid the drug side effects and possible harms to other parts of body. As the release process takes place gently during 4 days magnetically, this drug delivery system should be considered as one of the best candidates in azathioprine delivery.

\section{REFERENCES}

Akhtar, M. N., Chen, Y. C., AlDamen, M. A., \& Tong, M. L. (2017). 3D oxalato-bridged lanthanide (III) MOFs with magnetocaloric, magnetic and photoluminescence properties. Dalton Transactions, 46(1), 116-124.

Ananthoji, R., Eubank, J. F., Nouar, F., Mouttaki, H., Eddaoudi, M., \& Harmon, J. P. (2011). Symbiosis of zeolite-like metal-organic frameworks (rho-ZMOF) and hydrogels: Composites for controlled drug release. Journal of Materials Chemistry, 21(26), 9587-9594.

Colella, C. (2011). A critical reconsideration of biomedical and veterinary applications of natural zeolites. Clay Minerals, 46(2), 295-309.

Deria, P., Yu, J., Balaraman, R. P., Mashni, J., \& White, S. N. (2016). Topology-dependent emissive properties of zirconium-based porphyrin MOFs. Chemical Communications, 52(88), 13031-13034.

Dobson, J. (2006). Magnetic nanoparticles for drug delivery. Drug development research, 67(1), 55-60.

Goodwin, S., Peterson, C., Hoh, C., \& Bittner, C. (1999). Targeting and retention of magnetic targeted carriers (MTCs) enhancing intra-arterial chemotherapy. Journal of Magnetism and Magnetic Materials, 194(1-3), 132139.

Gupta, V., Mohiyuddin, S., Sachdev, A., Soni, P. K., Gopinath, P., \& Tyagi, S. (2019). PEG functionalized zirconium dicarboxylate MOFs for docetaxel drug delivery in vitro. Journal of Drug Delivery Science and Technology, 52, 846-855.

Huang, Y.-S., Lu, Y.-J., \& Chen, J.-P. (2017). Magnetic graphene oxide as a carrier for targeted delivery of chemotherapy drugs in cancer therapy. Journal of Magnetism and Magnetic Materials, 427, 34-40.

Hughes, G. A. (2005). Nanostructure-mediated drug delivery. Nanomedicine: nanotechnology, biology and medicine, 1(1), 22-30.

Ibrahim, M., Sabouni, R., \& A Husseini, G. (2017). Anti-cancer drug delivery using metal organic frameworks (MOFs). Current medicinal chemistry, 24(2), 193-214.

Janiak, C., \& Vieth, J. K. (2010). MOFs, MILs and more: concepts, properties and applications for porous coordination networks (PCNs). New Journal of Chemistry, 34(11), 2366-2388. 
Lazaro, I. A., \& Forgan, R. S. (2019). Application of zirconium MOFs in drug delivery and biomedicine. Coordination Chemistry Reviews, 380, 230-259.

Lee, Y. R., Kim, J., \& Ahn, W. S. (2013). Synthesis of metal-organic frameworks: A mini review. Korean Journal of Chemical Engineering, 30(9), 1667-1680.

Li, J., \& Mooney, D. J. (2016). Designing hydrogels for controlled drug delivery. Nature Reviews Materials, $1(12), 1-17$.

Lübbe, A. S., Alexiou, C., \& Bergemann, C. (2001). Clinical applications of magnetic drug targeting. Journal of Surgical Research, 95(2), 200-206.

McBain, S. C., Yiu, H. H., \& Dobson, J. (2008). Magnetic nanoparticles for gene and drug delivery. International journal of nanomedicine, 3(2), 169.

Orellana-Tavra, C., Köppen, M., Li, A., Stock, N., \& Fairen-Jimenez, D. (2020). Biocompatible, crystalline, and amorphous bismuth-based metal-organic frameworks for drug delivery. ACS applied materials \& interfaces, 12(5), 5633-5641.

Park, K. M., Kim, H., Murray, J., Koo, J., \& Kim, K. (2017). A facile preparation method for nanosized MOFs as a multifunctional material for cellular imaging and drug delivery. Supramolecular Chemistry, 29(6), 441 445 .

Parveen, S., Misra, R., \& Sahoo, S. K. (2012). Nanoparticles: a boon to drug delivery, therapeutics, diagnostics and imaging. Nanomedicine: Nanotechnology, Biology and Medicine, 8(2), 147-166.

Reinsch, H., van der Veen, M. A., Gil, B., Marszalek, B., Verbiest, T., De Vos, D., \& Stock, N. (2013). Structures, sorption characteristics, and nonlinear optical properties of a new series of highly stable aluminum MOFs. Chemistry of Materials, 25(1), 17-26.

Shekhah, O., Liu, J., Fischer, R. A., \& Wöll, C. (2011). MOF thin films: existing and future applications. Chemical Society Reviews, 40(2), 1081-1106.

Tibbitt, M. W., Dahlman, J. E., \& Langer, R. (2016). Emerging frontiers in drug delivery. Journal of the American Chemical Society, 138(3), 704-717.

Vader, P., Mol, E. A., Pasterkamp, G., \& Schiffelers, R. M. (2016). Extracellular vesicles for drug delivery. Advanced drug delivery reviews, 106, 148-156.

Webber, M. J., \& Langer, R. (2017). Drug delivery by supramolecular design. Chemical Society Reviews, 46(21), 6600-6620.

Xie, Y., Liu, X., Ma, X., Duan, Y., Yao, Y., \& Cai, Q. (2018). Small titanium-based MOFS prepared with the introduction of tetraethyl orthosilicate and their potential for use in drug delivery. ACS applied materials \& interfaces, 10(16), 13325-13332.

Xue, Z., Zhu, M., Dong, Y., Feng, T., Chen, Z., Feng, Y., ... \& Meng, S. (2019). An integrated targeting drug delivery system based on the hybridization of graphdiyne and MOFs for visualized cancer therapy. Nanoscale, 11(24), 11709-11718. 